\title{
Neuropathic arthropathy of the shoulder joint caused by syringomyelia: report of a rare case
}

\author{
Priyam Choudhury, ${ }^{1}$ Ashutosh Mohapatra, ${ }^{2}$ Amit Kharat, ${ }^{1}$ Vishva Chauhan ${ }^{1}$
}

'Department of Radiology, Dr DY Patil Medical College and Hospital, DY Patil Vidyapeeth, Pimpri, Maharashtra, India ${ }^{2}$ Department of Orthopaedics, Mohapatra Hospital, Ulhasnagar, India

\section{Correspondence to} Priyam Choudhury, priyamchoudhury28@gmail.com

Accepted 12 February 2019

\section{DESCRIPTION}

A 48-year-old man, farmer by occupation, presented to the outpatient department with pain, swelling and decreased movements of the right shoulder joint since 3 months. The symptoms had worsened since the past few days with the patient being unable to lift his right hand over his shoulder. Neither was there any history of significant trauma nor any fever, chills, anorexia, weight loss or any other constitutional symptoms. The patient took treatment from a local doctor but did not have any relief. Physical examination revealed a diffused swelling of the right shoulder along with a restricted and painful range of motion. The passive movements and active movements had the following values:abduction 50, flexion 40, and internal and external rotation 20 and 30, respectively. A thorough neurological examination revealed shoulder abductor power 3, shoulder flexor and extensor power 3 , biceps power 4 and triceps power 4 while the motor strength of the distal extremity was power 5. Right upper limb showed hypoesthesia and reduced temperature sensation with intact vibratory and propioreceptive sensations. The routine haematological and biochemical investigations were normal. Digital radiograph of the right shoulder revealed destruction of the humeral head (red arrow) with cortical irregularity in the acromion process and distal end of clavicle (figure 1). We decided to radiologically assess the patient further in the form of MRI right shoulder joint which showed non-visualisation of the humeral head and glenoid cavity with an

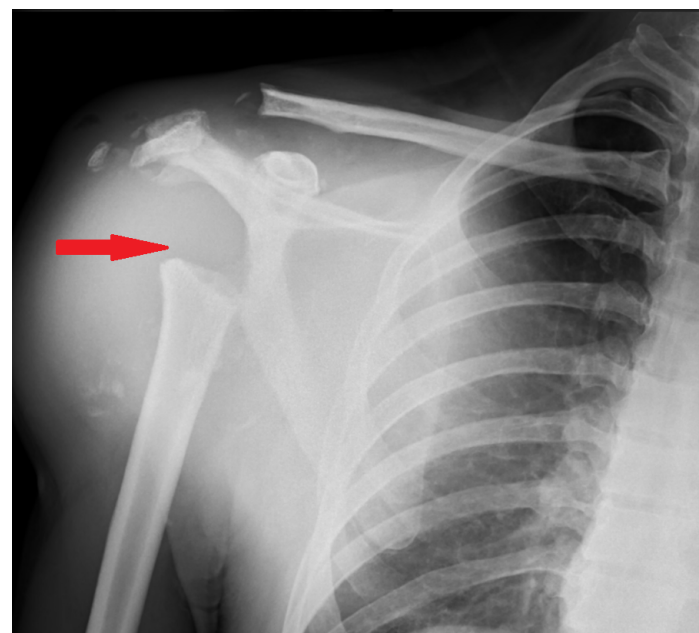

Figure 1 Digital radiograph of the right shoulder joint (anteroposterior view) showing destruction of the humeral head (red arrow) and glenoid cavity with cortical irregularity. Diffuse soft tissue haziness can also be seen distending the joint cavity with loose bodies within.

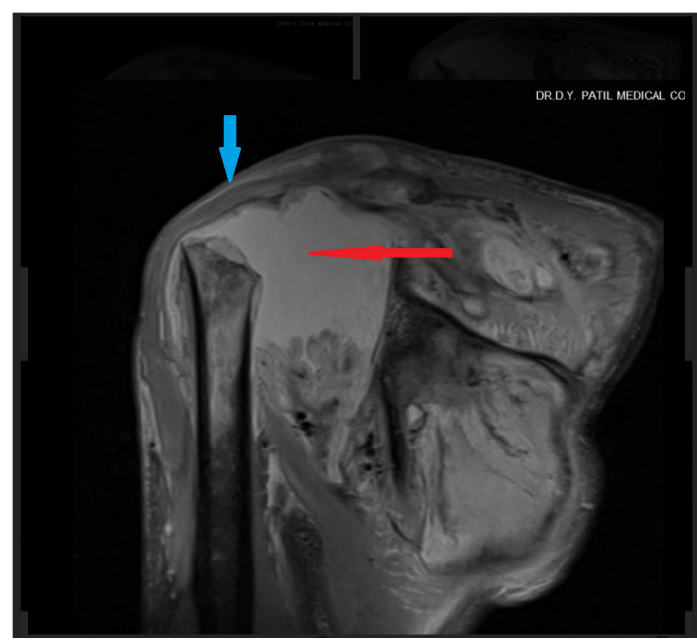

Figure 2 MRI right shoulder joint (Proton density coronal view) showing non-visualisation of the humeral head and glenoid cavity with an irregular collection (red arrow). Thinning of the deltoid muscle is seen too (blue arrow).

irregular collection and thinning of deltoid (figure 2). Based on the above findings, a provisional diagnosis of neuropathic arthropathy of the right shoulder joint was made. However, we did perform a joint aspiration to rule out any possibility of infection which

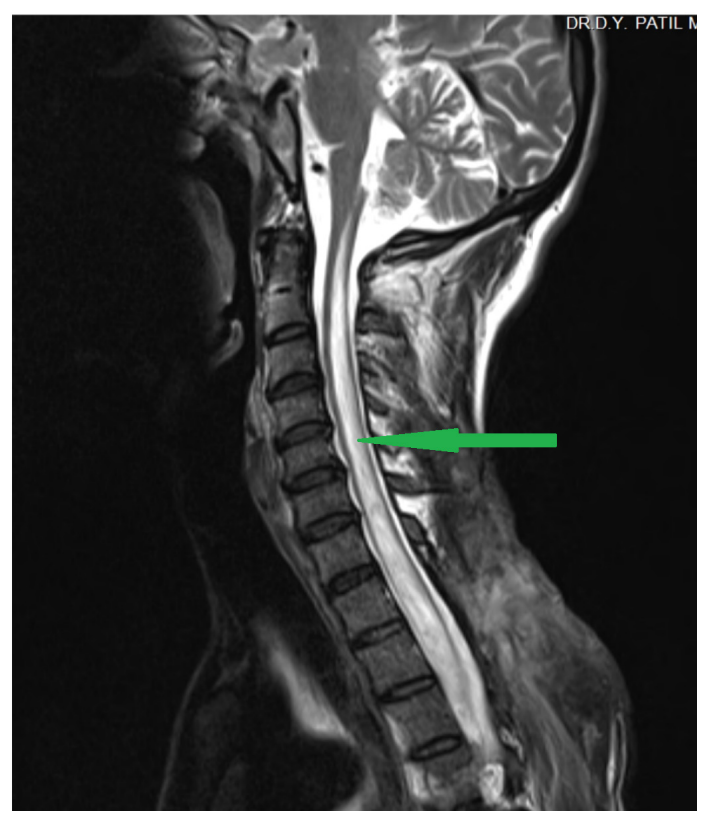

Figure 3 MRI cervical spine (T2-weighted saggital) image revealing a hyperintense syrinx in the central portion of the spinal cord (green arrow). 
was negative. MRI cervical spine done to investigate the aetiology revealed a syrinx in the central portion of the spinal cord (figure 3). A diagnosis of neuropathic arthropathy of the right shoulder joint due to syringomelia was made. Conservative mode of treatment was started in the form of non-steroidal anti-inflammatory drugs along with the application of a protective brace for the shoulder. The patient underwent an aggressive rehabilitation process for 6 months and at the end showed significant improvement in pain and mobility. Currently, the patient is able to do activities of daily living and is satisfied.

Neuropathic osteoarthropathy also known as Charcot's neuroarthropathy, is a chronic, degenerative arthropathy and

\section{Learning points}

- Charcot's arthropathy is a rare entity with few cases being reported till now.

- Once a diagnosis has been made, aetiology should be investigated in terms of a joint aspiration for infection and tumour and if negative then an MRI should be performed for syringomelia. is associated with decreased sensory innervation. ${ }^{1}$ Various causes include syringomelia (25\%), diabetes mellitus $(0.16 \%$ to $25 \%)$ and tabes dorsalis (5\% to $10 \%) .^{2}$ The key to preventing the progression of the disease is treatment of the underlying neuropathic process. ${ }^{3}$

Contributors $\mathrm{AM}$ and $\mathrm{PC}$ drafted the article and revised it critically for important intellectual content. AM did the literature search. VC and AK approved the final version to be published. $P C$ is responsible for the article to ensure that all questions regarding the article are investigated and resolved.

Funding The authors have not declared a specific grant for this research from any funding agency in the public, commercial or not-for-profit sectors.

Competing interests None declared.

Patient consent for publication Not required.

Provenance and peer review Not commissioned; externally peer reviewed.

\section{REFERENCES}

1 Shapiro G, Bostrom M. Heterotopic ossification and Charcot neuroarthropathy. Chapman MW, ed. Chapman's orthopaedic surgery. Philadelphia: Lippincott Williams \& Wilkins, 2001:3245-62.

2 Jones J, Wolf S. Neuropathic shoulder arthropathy (Charcot joint) associated with syringomyelia. Neurology 1998;50:825-7.

3 Nambiar M, Onggo JR, Pai V. Neuropathic arthropathy of the shoulder joint secondary to a syringomyelia. BMJ Case Rep 2018;11:bcr-2018-228228.

Copyright 2019 BMJ Publishing Group. All rights reserved. For permission to reuse any of this content visit https://www.bmj.com/company/products-services/rights-and-licensing/permissions/

BMJ Case Report Fellows may re-use this article for personal use and teaching without any further permission.

Become a Fellow of BMJ Case Reports today and you can:

- Submit as many cases as you like

- Enjoy fast sympathetic peer review and rapid publication of accepted articles

- Access all the published articles

- Re-use any of the published material for personal use and teaching without further permission

For information on Institutional Fellowships contact consortiasales@bmjgroup.com

Visit casereports.bmj.com for more articles like this and to become a Fellow 